\title{
生薬学担当教員による漢方教育に対する取り組み
}

\author{
三巻 祥浩, ${ }^{*, a}$ 小林 義 典, ${ }^{b}$ 牧野利 明 $c$
}

\section{Approach to the Education of Kampo Medicine by Pharmacognosy Faculty}

Yoshihiro Mimaki, ${ }^{*, a}$ Yoshinori Kobayashi, ${ }^{b}$ and Toshiaki Makino ${ }^{c}$

${ }^{a}$ School of Pharmacy, Tokyo University of Pharmacy and Life Sciences; 1432-1 Horinouchi, Hachioji, Tokyo 192-0392, Japan: ${ }^{b}$ School of Pharmacy, Kitasato University; 5-9-1 Shirokane, Minato-ku, Tokyo 108-8641, Japan: and 'Graduate School of Pharmaceutical Sciences, Nagoya City University; 3-1 Tanabe-dori, Mizuho-ku, Nagoya 467-8603, Japan.

わが国の明治以降の医療は西洋医学が中心であっ たが，近年，漢方医学が見なおされ，医師の 9 割ほ どがなんらかの形で漢方薬を処方した経験を持って いると言われている. 漢方医薬学研究の成果として 漢方薬の有効性のエビデンスが集積され，併せて医 学部において漢方医学教育が必修化されたことか ら, 今後, 日常診療で漢方薬を常時処方する医師は さらに増えることが推定される，また，医療費削減 の一環としてセルフメディケーションが推進されて いるが，セルフメディケーションにおける漢方薬の 期待は大きい.このような最近の医療動向を背景に, 6 年制の薬剤師教育のモデル・コアカリキュラムで は, 「C 薬学専門教育・化学系薬学を学ぶ C7 自然 が生み出す薬物」のなかに, 従来の生薬学（生薬の 基原, 成分, 薬効) と天然物化学（天然物の化学構 造と生合成，医薬品への応用）に加え，「現代医療 の中の生薬・漢方薬」の項目が取り入れられた.こ れにより，多くの薬学部で漢方薬に関する講義や実 習が必修化された。また，これに先立ち，漢方に関 する卒後教育・生涯学習を目的に, 日本生薬学会と 薬剂師研修センターは漢方薬・生薬認定薬剂師研修 制度を設け, 現在 3000 名近くの薬剂師が漢方薬 ・ 生薬認定薬剤師となっている.

平成 27 年度薬学部入学生から, 新しい薬学モデ ル・コアカリキュラムでの教育が開始された。旧モ

\footnotetext{
$a$ 東京薬科大学薬学部（干192-0392 東京都八王子市堀 之内 1432-1), $b$ 北里大学薬学部 (T108-8641 東京都 港区白金 5-9-1), c名古屋市立大学大学院薬学研究科 （广467-8603 名古屋市瑞穂区田辺通 3-1）

*e-mail:mimakiy@toyaku.ac.jp

日本薬学会 135 年会シンポジウム S56 序文
}

デル・コアカリキュラムにおいては，漢方に関する 内容が「C 薬学専門教育・化学系薬学を学ぶ」に配 置されていたが, 新モデル・コアカリキュラムでは それが「E2 薬理・病態・薬物治療 (10) 医療の中 の漢方薬」に移行された. E2 項 (10)の一般目標 (general instructional objective; GIO) は「漢方の 考え方, 疾患概念, 代表的な漢方薬の適応, 副作用 や注意事項などに関する基本的事項を習得する」で ある。このように漢方に関する内容が完全に「薬 理・病態・薬物治療」に移行され, 併せてその GIO が精査されたことで, 漢方の講義担当者とし て「どの専門分野の教員がふさわしいのか」, 「従来 の生薬学担当教員が適切なのか」, それとも「薬理・ 疾病・薬物治療分野の教員が担当すべきではない か」など, 各大学でいろいろと議論があったことが 推察される.

漢方薬は言うまでもなく複数の生薬を組み合わせ て用いる薬物であり, その薬効や副作用, 相互作用 などを理解するうえでは生薬学の基礎知識を無視し ては語れないであろう。したがって, 漢方薬の適応 外の使用方法も含めた高度な臨床応用に関する内容 は別として, 薬学部において漢方薬の基礎に相当す る部分は生薬学を基盤に, 生薬に精通した生薬学担 当教員が担当することが妥当ではないだろうか.

本シンポジウムは, 生薬学担当教員の漢方薬に関 する教育手法の共有を目的に企画したものである. 早い時期から漢方に関連した講義を担当してきた生 薬学担当の先生方から講義の具体的な内容と工夫を ご紹介して頂くとともに，医療現場（病院）及び医 療用漢方エキス剤のメーカー側から大学での漢方教 育に期待すること，漢方の国際化時代における漢方 
教育のあり方についても議論を行つた.

シンポジストと講演題目は以下の通りである.

小池一男 (東邦大学薬学部)「東邦大学薬学部で の漢方教育の取り組み」

松田久司（京都薬科大学）「京都薬科大学での漢 方教育の取り組み」

牧野利明 (名古屋市立大学大学院薬学研究科) 「漢方の国際化時代における漢方教育のあり方」

本間真人（筑波大学附属病院薬剤部）「医療現場 側から大学での漢方教育に期待すること」

石田雅規（株式会社ツムラ医薬研修部）「企業に
おける漢方教育の考え方」

小林義典（北里大学薬学部）「新薬学教育モデ ル・コアカリキュラムにおける漢方教育」

本誌上シンポジウムは，このうち石田雅規氏（株 式会社ツムラ医薬研修部）を除く 5 名のシンポジス トによる Symposium Review からなる。

漢方薬に関する講義は, 薬用植物学や生薬学の講 義が一通り終わった 2 年次後期から 3 年次に開講さ れる大学が多いと思われる。本シンポジウムの内容 が，生薬学担当教員の漢方薬に関する講義の一助に なれば幸いである. 